\title{
Knowledge and Behaviour of Young People Concerning Fertility Risks - Results of a Questionnaire
}

\author{
Wissen und Verhalten junger Menschen bezüglich Fertilitätsrisiken - \\ Ergebnisse einer Befragung
}

Authors

Affiliations
J. Fügener ${ }^{1}$, A. Matthes ${ }^{2}$, B. Strauß ${ }^{1}$

1 Institut für Psychosoziale Medizin und Psychotherapie, Universitätsklinikum Jena, Jena

2 Klinik für Psychiatrie und Psychotherapie, Universitätsklinikum Jena, Jena

\author{
Key words \\ - knowledge about fertility \\ - lifestyle \\ - involuntary childlessness \\ prevention \\ Schlüsselwörter \\ - Wissen zur Fertilität \\ - Lifestyle \\ - ungewollte Kinderlosigkeit \\ - Prävention
}

$\begin{array}{ll}\text { received } & 12.1 .2013 \\ \text { revised } & 18.6 .2013 \\ \text { accepted } & 26.7 .2013\end{array}$

Bibliography

DoI http://dx.doi.org/

10.1055/s-0033-1350761

Geburtsh Frauenheilk 2013; 73 : 800-807 (c) Georg Thieme

Verlag KG Stuttgart - New York . ISSN 0016-5751

\footnotetext{
Correspondence

Josephine Fügener

Universitätsklinikum Jena Institut für Psychosoziale

Medizin und Psychotherapie

Stoystraße 3

07740 Jena

josephine.fuegener@

uni-jena.de
}

\section{Abstract}

$\nabla$

Purpose: The aim of this study was, in the light of the increasing number of involuntarily childless couples, to investigate the state of knowledge of young people of fertile age about the risks for fertility disorders and their own risk behaviour. In addition, we wanted to check for a relationship between these aspects and the motives for wanting children, individual personality traits and psychological status.

Materials and Methods: 498 women and men between the ages of 18 and 30 years participated in an anonymous survey. The sample consisted of 153 medical students, 190 students from other faculties and 155 vocational trainees. Their knowledge was tested by way of open questions on reproduction. The sum total from relevant life-style factors was used to estimate their risktaking behaviour. Their psychic states were examined using the Health Questionnaire for Patients "Gesundheitsfragebogen für Patienten" PHQ-D, in addition the Leipzig Questionnaire on Motives for Wanting Children "Der Leipziger Fragebogen zu Kinderwunschmotiven" and the short version of the "Big Five Inventory" BFI-K were used.

Results: The participants were aware of the risks for fertility disorders but did not always correctly assess their influence on fertility. Their knowledge about reproduction was rather low (on average 6.3 from 16 points). Medical students had a significantly higher state of knowledge and exhibited less risky behaviour as compared to the other two groups. Depressiveness and risky behaviour correlated positively and emotional aspects played the major role in attitudes towards having children. Risk behaviour was best predicted by the variables depressiveness, low level of knowledge and the feeling of being restricted in personal life by children.

Discussion: Lack of knowledge on the topics fertility and reproduction could be a reason for risky

\section{Zusammenfassung \\ $\nabla$}

Fragestellung: Ziel der Studie war es, angesichts steigender Zahlen ungewollt kinderloser Paare, den Wissensstand junger Menschen im fertilen Alter hinsichtlich Risiken für Fertilitätsstörungen und ihr eigenes Risikoverhalten zu beschreiben. Außerdem sollte ein Zusammenhang zwischen diesen Aspekten und den Kinderwunschmotiven, Persönlichkeitsmerkmalen und der psychischen Befindlichkeit geprüft werden.

Material und Methode: Es wurden 498 Frauen und Männer zwischen 18 und 30 Jahren schriftlich anonym befragt. Die Stichprobe bestand aus 153 Medizinstudierenden, 190 Studierenden anderer Fachrichtungen und 155 Berufsschülern. Das Wissen wurde anhand offener Fragen zur Reproduktion getestet. Zur Beurteilung des Risikoverhaltens wurde ein Summenwert aus relevanten Lifestyle-Faktoren gebildet. Die psychische Befindlichkeit wurde mit dem „Gesundheitsfragebogen für Patienten“ PHQ-D untersucht, weiterhin wurden „Der Leipziger Fragebogen zu Kinderwunschmotiven“ und die Kurzversion des „Big Five Inventory“ BFI-K eingesetzt.

Ergebnisse: Die Probanden kannten Risiken für Fertilitätsstörungen, wichteten aber ihren Einfluss auf die Fertilität nicht immer zutreffend. Das Wissen zur Reproduktion war eher gering (durchschnittlich 6,3 von 16 Punkten). Medizinstudierende hatten einen signifikant besseren Kenntnisstand und verhielten sich auch risikoärmer als die anderen beiden Gruppen. Depressivität und Risikoverhalten korrelierten positiv, emotionale Aspekte spielten für die Einstellung zum Kinderwunsch die größte Rolle. Risikoverhalten ließ sich am besten durch die Variablen Depressivität, mangelndes Wissen und das Gefühl, durch Kinder persönlich eingeschränkt zu sein, vorhersagen.

Diskussion: Wissenslücken zum Thema Fertilität und Reproduktion können ein Grund für risiko- 
behaviour and thus have a negative impact on lifestyle factors relating to fertility. Young people are aware of the risk factors that may affect fertility but do not always act accordingly. Primary prevention or, respectively, health promotion is thus necessary to prevent further increases in the number of infertile couples.

\section{Introduction}

$\nabla$

The low birth rate and the thus resulting childlessness in Germany has become a much discussed topic only in the past few years although the birth rate has, for more than 30 years, been at a constant level of about 1.4 children per woman and thus amongst the lowest worldwide. In order to maintain a constant population size about 2.1 children per women would be needed. The average number of children is essentially influenced by 2 factors: the number of children per mother, which is generally rather stable, and the number of childless women, which has continuously increased over the past decades and thus is to be considered as the decisive factor for the low birth rate [1].

The demographic changes resulting from this childlessness have become a societal problem: according to data from the Federal Statistics Office in $2008,21 \%$ of the 40 - to 44 -year-old women had not given birth to a child whereas, in contrast, among the 10 or, respectively 20 year older women only 16 or, respectively, $12 \%$ were childless [1]. In Germany, women desire on average 1.75 children and with this number are already at the bottom of the list in Europe [2]. If each woman really did give birth to about 1.7 children, the population of Germany, with an annual migration plus of 200000 persons, would more or less remain constant [3]. Since only about 1.4 children per women are actually born without consideration of immigration - each new generation would be about one third smaller than that of their parents; at this rate the population would decline to one third within three generations [3].

Stöbel-Richter et al. reported not only on an increase in voluntary childlessness but also an increase in involuntary childlessness due to fertility disorders [4]. According to a survey by the Allensbach Demoscopic Institute, merely about $8 \%$ of German adults aged between 25 and 59 years explicitly did not or do not want to have children [3], more than $30 \%$ of this age group do not have or do not yet have children. $22 \%$ of the age group wish to have or have previously wished to have children (14\%). Altogether, therefore for about $36 \%$ of the surveyed men and women the desire for a first or a further child has not yet been fulfilled. Social reasons, such as the lack of a stable partnership [3], financial considerations (according to economic studies childless families are better off than families with children) or medical factors could be responsible for this.

The distinction between voluntary and involuntary childlessness is not always easy. Many couples put off having children due to career planning and/or feel that they are still too young to have children. Then, when the individually appropriate point in time for parenthood has been found, an initially voluntary childlessness can rapidly become an involuntary childlessness since fertility decreases with age of the man and especially of the woman [3]. The blame lies mainly with the decreasing quality of sperm and egg cells. For women over the age of 30 years every additional year of life is associated with a $13 \%$ reduction of the chance to give birth to a living baby [5]. In a review published in 2007, Homan et al. [6] investigated further the lifestyle factors that impact reiches Verhalten und somit für einen negativen Einfluss von Lifestyle-Faktoren auf die Fertilität sein. Junge Menschen kennen zwar Risikofaktoren, welche die Fruchtbarkeit beeinflussen, verhalten sich aber nicht immer entsprechend. Primärprävention bzw. Aufklärung sind deshalb nötig, um eine weiter steigende Zahl infertiler Paare zu verhindern.

on fertility: besides increasing age, the negative influence of weight and nicotine consumption is undisputed. Not only underweight but also overweight due to disturbances of the hormone household and ovarian dysfunction have decisive effects on fertility: women with a BMI $>25$ or $<19 \mathrm{~kg} / \mathrm{m}^{2}$ have a higher risk that a pregnancy occurs after more than 12 months than a woman of normal weight [7]. The prevention of eating disorders already at school age is thus of major importance [8]. Smoking has both negative effects on the fertility of men with regard to the production, mobility and morphology of sperm, accompanied by an increased number of DNA damages to germ cells [9] and also in women it leads to disturbances in the maturation of egg cells and disorders of the hormone system during the luteal phase. In addition the length of the fertile period of smoking women is reduced due to the earlier start of menopause (on average 1-4 years earlier) [10].

Possible effects of eating habits, lack of physical activity, mental stress, as well as caffeine and nicotine abuse on spontaneous reproduction are still being discussed controversially in the literature [11]; however, the favourable influence of their avoidance on general health is not disputed. A randomised, controlled study on the question of whether prevention - for example, a life-style counselling - can have a positive effect in the population at risk is not available [12]. Still relatively unclear up to now are common attitudes and myths regarding fertility, especially among young people, and the question as to what is actually known and present with regard to fertility reducing risk factors in the population. Many people, for example, seem not to be aware that they lose chances when they postpone their wish to start a family. In recent studies (Bunting and Boivin 2008 [13]; Bretherick et al. 2010 [14]), concerning knowledge about the effects of certain life-style factors (among other age) on fertility, the participants knew only little about specific risks. In the study of Bunting and Boivin (2008) the participating female students wrongly believed in certain myths and "pseudo-protective factors" (e.g., higher fertility when living in the country, increased probability of conception after adoption).

The involuntary failure to become pregnant may have various medical and biological reasons. The disorders are with 30-40\% each equally distributed among the genders; in about 15-30\% a combination of factors in both partners is found [3]. In women, apart from hormone imbalances, infections, e.g. with chlamydia, malformations and endometriosis are the major reasons, in men they are motility and formation disorders of sperm, rare testicular dysfunctions.

For the development of preventative measures, just that childless group of the population who want or would have liked to have children - according to an Allensbach survey this holds for about 1.4 million people in Germany - would be suitable to benefit from improvements of family politics as well as from information about possible effects of life-style factors on fertility. However, general experience shows that this group is only accessible with some difficulty [15]. 
The present cross-sectional study is intended to evaluate the knowledge of young people about life-style, fertility and risk factors for fertility as well as their risk behaviour and to set these aspects in relation to their attitudes to starting a family, personal characteristics and their mental health. Finally, the study should also provide leads for the further development of options to prevent fertility disorders.

\section{Materials and Methods \\ $\nabla$}

In the course of the study students and vocational trainees in the Jena region were questioned about their knowledge and behaviour concerning the risks for fertility disorders in a cross-sectional study by means of an anonymous questionnaire. Three distinct groups were formed: medical students at the Friedrich-Schiller University of Jena in the clinical semesters prior to starting the practical year (MS), students from other faculties of the same university (AS) and vocational trainees from the "Staatliches Berufsbildendes Schulzentrum Jena-Göschwitz" as well as from the "Staatliche Berufsbildende Schule für Gesundheit und Soziales Jena" (BS).

\section{Sample population}

498 young men and women aged between 18 and 30 years were enrolled as the sample population (average age $\mathrm{M}=22.04$ years, $\mathrm{SD}=2.5$, min. $=18$, $\max .=30)$. Of these 153 were medical students $(M=22.88, S D=2.1$, $\min .=20$, $\max .=30,69.3 \%$ female, $30.7 \%$ male), 190 were students from other faculties $(M=22.03$, $\mathrm{SD}=2.4$, min. $=18, \max .=30,56.3 \%$ female, $43.7 \%$ men $)$ and 155 were vocational trainees $(\mathrm{M}=21.23, \mathrm{SD}=2.8, \mathrm{~min} .=18$, $\max .=29,60.0 \%$ female, $40.0 \%$ male). Altogether, 306 women (61.4\%) and 192 men (38.6\%) returned the questionnaire. Most of them had as the highest previously attained educational certificate the German "Abitur" or, respectively, "Fachhochschulreife" (68.1\%), a smaller proportion had achieved a "Realschulabschluss" (24.1\%), a completed vocational training (3.8\%), completed university studies (3.0\%) or had an "Hauptschulabschluss" (1\%). In the group of students, the proportion with "Abitur" was, as to be expected, higher than among the vocational trainees, most of whom had a "Realschulabschluss" ( Table $\mathbf{1}$ ).

\section{Data collection instruments}

For the survey of fertility-related topics, the newly developed questionnaire with possible responses (yes/no answer options) and free text was used, the content of which is oriented on the study of Bunting and Boivin [13]. The form also includes sociodemographic characteristics with 6 items (profession/current employment, age, gender, height, weight, highest educational level reached to date), the actual state of knowledge on the subjects fertility and reproduction as well as their assessment (in total 43 items) and the living habits of the participants (22 items). Following the sociodemographic details, questions were posed concerning past confrontations with fertility disorders (yes/no answer) and, if appropriate, about the reasons (free text), known risks for fertility disorders in male and female (free text), and if the participants wished for comprehensive information about fertility disorders, e.g., in the form of posters (yes/no).

In a further section the participants were presented with items ( Table 2) which they should evaluate concerning the extent to which these modes of behaviour and living habits represent personal risks for fertility. These were to be answered using a 5-point scale from "yes, that applies to me" (= 5 points) to "no, that does not apply to me" (= 1 point). Finally, the three greatest risks for fertility in men and women had to be mentioned again.

The specific knowledge of the participants was assessed on the basis of 8 questions on the topic reproduction. In the process, the following aspects were questioned: age of the women at $50 \%$ decline in fertility, spontaneous pregnancy rate between 20-25 or, respectively, over 40 years of age, start and duration of the fertile days of a women in the menstrual cycle, duration of fertilisation ability of egg cells or, respectively, sperm, percentage of involuntarily childless couples in Germany. The results were scored with 0,1 or 2 points according to deviation from the correct answers and a sum total score was calculated. Depending on the point score achieved the participants were divided into 3 groups: low ( $0-5$ points), moderate (6-10 points) and good (1116 points) states of knowledge.

Finally, with the help of 18 items, a risk score for the participants was calculated. For each of the risk factors listed in $\square$ Table 3 a score of 1 point was given if it applied and the sum total was formed (maximum score: 25 points).

In addition, the "Leipziger Fragebogen zu Kinderwunschmotiven" (LKM, 20 items) was used as a standardised instrument, which assigns each of 5 items to one of the 4-factor analytically

Table 1 Sociodemographic characteristics of the sample population.

\begin{tabular}{|c|c|c|c|c|}
\hline & Medical students & Students from other faculties & Vocational trainees & Total \\
\hline Total n (\%) & $153(30.7 \%)$ & $190(38.2 \%)$ & $155(31.1 \%)$ & $498(100 \%)$ \\
\hline \multicolumn{5}{|l|}{ Alter } \\
\hline$>\mathrm{M}$ & 22.88 & 22.03 & 21.23 & 22.04 \\
\hline$>\mathrm{SD}$ & 2.14 & 2.38 & 2.75 & 2.51 \\
\hline \multicolumn{5}{|l|}{ Gender } \\
\hline - Female & $106(69.3 \%)$ & $107(56.3 \%)$ & $93(60.0 \%)$ & $306(61.4 \%)$ \\
\hline r Male & $47(30.7 \%)$ & $83(43.7 \%)$ & $62(40.0 \%)$ & $192(38.6 \%)$ \\
\hline \multicolumn{5}{|l|}{ School leaving certificate } \\
\hline - "Hauptschule" & 0 & 0 & $5(3.2 \%)$ & $5(1 \%)$ \\
\hline • "Realschule" & 0 & 0 & $120(77.4 \%)$ & $120(24.1 \%)$ \\
\hline > "Abitur" & $149(97.4 \%)$ & $178(93.7 \%)$ & $12(7.7 \%)$ & $339(68.1 \%)$ \\
\hline - completed vocational training & 0 & $1(0.5 \%)$ & $18(11.6 \%)$ & $19(3.8 \%)$ \\
\hline - completed university studies & $4(2.6 \%)$ & $11(5.8 \%)$ & 0 & $15(3.0 \%)$ \\
\hline
\end{tabular}

M: mean value, SD: standard deviation 
Table 2 Assessment of the risks for fertility: mean values and standard deviations for the 3 subgroups as compared by a univariate ANOVA. The factors were estimated according to a scale from 1 ("no, that does not apply to me") to 5 ("yes, that applies to me" (factors that were evaluated to be significantly different are printed in bold type).

\begin{tabular}{|c|c|c|c|c|c|c|c|c|c|c|}
\hline Factor & $\begin{array}{l}\text { M - } \\
\text { MS }\end{array}$ & $\begin{array}{l}\text { SD - } \\
\text { MS }\end{array}$ & $\begin{array}{l}\text { M - } \\
\text { AS }\end{array}$ & $\begin{array}{l}\text { SD - } \\
\text { AS }\end{array}$ & $\begin{array}{l}M- \\
\text { BS }\end{array}$ & $\begin{array}{l}\text { SD - } \\
\text { BS }\end{array}$ & $\begin{array}{l}\mathrm{M}- \\
\text { total }\end{array}$ & $\begin{array}{l}\text { SD - } \\
\text { total }\end{array}$ & $F(2)$ & $\mathbf{p}$ \\
\hline Drugs & 4.63 & 0.78 & 4.72 & 0.73 & 4.51 & 1.10 & 4.63 & 0.88 & 2.42 & 0.090 \\
\hline Increasing age in women & 4.78 & 0.57 & 4.63 & 0.70 & 4.43 & 1.06 & 4.61 & 0.80 & 7.34 & 0.001 \\
\hline Hormone disorders & 4.86 & 0.49 & 4.50 & 0.91 & 4.31 & 1.09 & 4.55 & 0.90 & 15.59 & $<0.001$ \\
\hline Radiation/irradiation & 4.77 & 0.56 & 4.49 & 0.84 & 4.36 & 1.13 & 4.54 & 0.89 & 9.07 & $<0.001$ \\
\hline Alcohol & 4.52 & 0.75 & 4.57 & 0.72 & 4.42 & 1.01 & 4.51 & 0.83 & 1.55 & 0.214 \\
\hline Smoking & 4.46 & 0.84 & 4.49 & 0.83 & 4.38 & 0.97 & 4.45 & 0.88 & 0.76 & 0.467 \\
\hline Chemotherapy & 4.73 & 0.64 & 4.37 & 0.91 & 4.25 & 1.16 & 4.44 & 0.95 & 11.55 & $<0.001$ \\
\hline Diseases of the genital organs & 4.39 & 0.80 & 4.29 & 0.88 & 4.21 & 1.06 & 4.30 & 0.92 & 1.35 & 0.261 \\
\hline Doping & 4.50 & 0.85 & 4.19 & 0.98 & 4.17 & 1.20 & 4.28 & 1.03 & 5.15 & 0.006 \\
\hline Genetic predisposition & 4.36 & 0.82 & 4.24 & 0.86 & 4.01 & 1.19 & 4.21 & 0.97 & 5.12 & 0.006 \\
\hline Injuries/operations in the genital region & 4.39 & 0.78 & 4.10 & 1.00 & 4.02 & 1.13 & 4.17 & 0.99 & 6.20 & 0.002 \\
\hline Stress & 4.41 & 0.67 & 4.09 & 0.78 & 3.99 & 0.94 & 4.16 & 0.82 & 10.97 & $<0.001$ \\
\hline Underweight & 4.68 & 0.69 & 4.00 & 1.05 & 3.82 & 1.35 & 4.15 & 1.12 & 28.29 & $<0.001$ \\
\hline Use of medicaments & 4.13 & 0.86 & 4.13 & 0.90 & 4.08 & 1.11 & 4.11 & 0.95 & 0.15 & 0.862 \\
\hline Sexually transmitted diseases & 4.29 & 0.98 & 3.86 & 1.09 & 3.95 & 1.25 & 4.02 & 1.12 & 6.90 & 0.001 \\
\hline Overweight & 3.80 & 1.14 & 3.69 & 1.21 & 3.84 & 1.29 & 3.77 & 1.22 & 0.69 & 0.504 \\
\hline Reversal of a sterilisation & 3.84 & 1.19 & 3.83 & 1.15 & 3.56 & 1.39 & 3.75 & 1.25 & 2.66 & 0.071 \\
\hline Increasing age in men & 3.65 & 1.28 & 3.74 & 1.31 & 3.72 & 1.44 & 3.70 & 1.34 & 0.21 & 0.815 \\
\hline Depression & 3.78 & 0.99 & 3.56 & 1.10 & 3.55 & 1.26 & 3.62 & 1.12 & 2.11 & 0.122 \\
\hline Mental stress & 3.92 & 0.94 & 3.47 & 1.20 & 3.29 & 1.33 & 3.55 & 1.20 & 11.74 & $<0.001$ \\
\hline Environmental pollution & 3.84 & 1.01 & 3.43 & 1.00 & 3.25 & 1.25 & 3.50 & 1.11 & 11.58 & $<0.001$ \\
\hline Physical complaints & 3.41 & 1.11 & 3.33 & 1.05 & 3.35 & 1.14 & 3.36 & 1.10 & 0.26 & 0.775 \\
\hline Chronic diseases & 3,63 & 1.16 & 3.27 & 1.03 & 3.14 & 1.18 & 3.34 & 1.14 & 8.04 & $<0.001$ \\
\hline Anxiety disorder & 3.67 & 1.05 & 3.25 & 1.12 & 3.13 & 1.27 & 3.34 & 1.17 & 9.40 & $<0.001$ \\
\hline Diseases of the immune system & 3.45 & 0.91 & 3.24 & 1.01 & 3.11 & 1.13 & 3.26 & 1.03 & 4.34 & 0.014 \\
\hline Paediatric diseases, e. g., mumps & 3.50 & 1.35 & 3.06 & 1.31 & 2.99 & 1.32 & 3.18 & 1.34 & 6.78 & 0.001 \\
\hline Competitive sports & 3.53 & 1.16 & 2.84 & 1.23 & 2.65 & 1.24 & 2.99 & 1.27 & 22.32 & $<0.001$ \\
\hline Sleeping problems & 2.79 & 0.92 & 2.79 & 1.06 & 2.81 & 1.22 & 2.79 & 1.07 & 0.11 & 0.989 \\
\hline Lack of exercise & 2.63 & 1.12 & 2.76 & 0.98 & 2.88 & 1.26 & 2.76 & 1.12 & 2.02 & 0.134 \\
\hline
\end{tabular}

MS: medical students, AS: students from other faculties, BS: vocational trainees, M: mean value, SD: standard deviation, univariate ANOVA: F(df): $\mathrm{F}$ value, df: degree of freedom (=2), p: significance, error probability $\mathrm{p}<0.05$

constructed scales "emotional stabilisation and leading a meaningful life", "personal limitations and problems", "social recognition and creation of identity" as well as "insufficient material and social support" [16]. Furthermore, the "Big Five Inventory" (BFI-K, 21 Items) was employed that allows an assessment of the 5 -factor model of personality in a shorter time than the original, but with an also satisfactory psychometric characterisation [17]. Last but not least, the "Gesundheitsfragebogen für Patienten" (short form PHQ-D, 15 items) tests for depressive disorders, panic disorders and the general psychosocial functional capacity [18]. It is known that especially affective symptoms can decisively influence health behaviour including prevention [19]. This holds particularly well for depressive symptoms that are often associated with a negative attitude towards one's own personal status and the future. Against this background the present study has explicitly investigated a relationship between depressiveness (assessed by means of the PHQ-D) and risk behaviour. In the PHQ-D (maximum sum score: 27 points) a sum score of less than 5 corresponds to the absence of a depressive disorder whereas a score of 5-10 characterises a mild or latent depressive disorder of mild severity, scores of 10 or more are characteristic of a major depression [18].

\section{Statistical analysis}

The statistical evaluation was made with the help of the software package SPSS Version 19. Besides descriptive statistics, Spearman correlation coefficients were calculated, subgroups were compared by means of t tests or, respectively, univariate ANOVA. Finally, multiple stepwise regressions were calculated to predict the risk of a fertility disorder. A value of $\mathrm{p}<0.05$ was set as the error probability.

\section{Results}

\section{Addressing the issue}

In the survey merely $22.5 \%$ of the participants reported that they had already concerned themselves at least once with the risks for fertility disorders. Whereas among the AS only $14.7 \%$ had been previously confronted with the topic, the corresponding numbers among the BS with $20.6 \%$ and the MS with $34.0 \%$ were significantly higher $(F[1]=7.88, p=0.005)$. Clear differences were also apparent between the sexes, women comprised the larger portion $(74 \%)$ of those who had already addressed the issue ( $\mathrm{F}$ $[1]=6.13, p=0.014) .58 .7 \%$ of these women gave a reason for their consideration of the risks for infertility, most frequently named were experiencing themselves a disease or operation (3.2\% referred to the total population), followed by occurrence 
Table 3 Overview of the variables included in the calculation of a risk score for each individual participant (and its weighting).

\begin{tabular}{|c|c|}
\hline Risk factor & $\begin{array}{l}\text { Evaluation } \\
\text { (in points) }\end{array}$ \\
\hline Lack of exercise & 1 \\
\hline Competitive sport & 1 \\
\hline Doping & 1 \\
\hline $\begin{array}{l}\text { Gain or loss of weight of more than } 10 \mathrm{~kg} \text { within } \\
\text { a 6-month period }\end{array}$ & 1 \\
\hline Heavy manual work in profession & 1 \\
\hline \multicolumn{2}{|l|}{ Nicotine abuse: } \\
\hline - less than 10 cigarettes per day & 1 \\
\hline - more than 10 cigarettes per day & 2 \\
\hline $\begin{array}{l}\text { Alcohol consumption (more than } 2 \text { glasses of alcohol } \\
\text { per day) }\end{array}$ & 1 \\
\hline Regular consumption of drugs* & 1 \\
\hline Sleep disorders & 1 \\
\hline \multicolumn{2}{|l|}{ Exposure to harmful environmental influences: } \\
\hline - less than 10 times per month & 1 \\
\hline - more than 10 times per month & 2 \\
\hline Chronic disease & 1 \\
\hline Treatment with chemotherapy or radiation & 1 \\
\hline Regular consumption of medications & 1 \\
\hline Lack of a stable relationship & 1 \\
\hline Sterilisation & 1 \\
\hline To date no gynaecological/urological examination & 1 \\
\hline No regular consultations with gynaecologist/urologist & 1 \\
\hline Suffering from an STD (sexually transmitted disease) & 1 \\
\hline Hormone disorders & 1 \\
\hline Own known fertility disorder & 1 \\
\hline Fertility disorders in family members & 1 \\
\hline \multicolumn{2}{|l|}{ Deviation of BMI (body mass index) from normal weight: } \\
\hline$><18.5 \mathrm{~kg} / \mathrm{m}^{2}$ & 1 \\
\hline$>>25 \mathrm{~kg} / \mathrm{m}^{2}$ & 1 \\
\hline $\begin{array}{l}\text { Reaching a scale sum score of more than } 5 \text { points } \\
\text { in the PHQ-D questionnaire (depressiveness) }\end{array}$ & 1 \\
\hline Sum score & $\begin{array}{l}\text { maximum } \\
25 \text { points }\end{array}$ \\
\hline
\end{tabular}

* Consumption of drugs should be specified (altogether 6.8\% of the participants reported consumption of "soft" drugs like hashish or marihuana)

of an unfulfilled wish for children or a miscarriage among friends $(2.8 \%)$ as well as involvement with the problem during their studies (2.2\%). Further considerations of the participants were an own pregnancy or a partner's pregnancy (1.2\%), confrontation with the topic during further education/training (1.0\%), the own unfulfilled desire for children ( $0-8 \%$ ), media coverage $(0.4 \%)$, late occurrence or absence of a period ( $0.4 \%)$, drug consumption or deliberations concerning taking the pill or having an HPV vaccination (each $0.2 \%$ ).

\section{Knowledge about fertility risks for woman and man}

In response to the request to name the known risks for fertility disorders or, respectively, infertility in women on average 2.84 answers were given. MS ( $M=3.52, \mathrm{~s}=2.09)$ were aware of significantly more risks than AS $(\mathrm{M}=2.58, \mathrm{~s}=1.71)$ and $\mathrm{BS}(\mathrm{M}=2-48$, $\mathrm{s}=1.95)(\mathrm{F}[2]=14.14, \mathrm{p}<0.001)$. Women mentioned on average 3.05 , men 2.51 risks in free text, this was significantly different $(F[1]=9.18, p=0.003)$. In order of naming, smoking was mentioned most frequently by all participants (38.4\%), followed by diseases of the genital organs (38.0\%) and consumption of drugs (23.7\%) ( Fig. 1). MS reported most frequently diseases of the sexual organs as a risk factor for female infertility (52.9\% within the professional group), followed by sexually transmitted diseases (STD, 37.9\%) and smoking (33.3\%). In the other two groups, smoking was mentioned the most often: among AS by $38.4 \%$, among BS by $43.2 \%$. Second and third places were taken by diseases of the genital tract (34.7\% among AS, $27.1 \%$ among BS) and drug consumption (25.2/31.0\%).

Factors that could lead to infertility in men were less known among the participants (on average 2.6 factors). Here also MS could name significantly more risks $(\mathrm{M}=3.12, \mathrm{~s}=2.00)$ than AS $(\mathrm{M}=2.39, \quad \mathrm{~S}=1.60)$ and $\mathrm{BS}(\mathrm{M}=2.35, \mathrm{~s}=1.94) \quad(\mathrm{F}[2]=8.72$, $\mathrm{p}<0.001)$. There were no significant differences between the answers of male and those of female participants. In order of mention by the entire population, smoking was again in first place (41.2\%), followed by diseases of the genital tract (28.1\%) and alcohol consumption (24.5\%) ( Fig. 1). In the MS group diseases of the genital tract were mentioned most frequently (44.4\% within the group), followed by smoking (35.3\%) and environmental factors (30.1\%). In the AS and BS groups, smoking took the first place (40.5/48.5\%), places 2 and 3 were taken by drug (26.3/29.0\%) and alcohol consumption (23.7/29.0\%).

\section{Wish for information}

Concerning the question as to whether they wanted comprehensive information about fertility disorders altogether $62.4 \%$ of the participants answered with "yes". Above all the AS group demonstrated a large need for information (64.7\%), among BS 61.9\%, and among MS 60.1\%. Men (50.5\%) expressed a desire for clarification less frequently than women (69.9\%) $(\mathrm{F}[1]=19.63$, $\mathrm{p}<0.001)$.

\section{Assessment of the risks for fertility}

In the differentiation of risks according to their relevance for fertility, on the whole drugs were named as the factor with the most influence $(M=4.63, s=0.88$, min. $=1$, $\max .=5)$, followed by increasing age of the woman $(\mathrm{M}=4.61, \mathrm{~s}=0.80)$ and hormone disorders $(\mathrm{M}=4.55, \mathrm{~s}=0.90)$. Merely 3 of the given items were considered to rather have no influence on fertility: competitive sports $(M=2.99)$, sleeping problems $(M=2.79)$ and lack of exercise $(\mathrm{M}=2.76$, 0 Table 2$)$.

Whereas the AS and BS groups placed the most weight on drug consumption, increasing age of the women and alcohol consumption, the MS group named in order hormone disorders, increasing age of the women and radiation/irradiation as being by far the most important factors. Altogether 17 items were considered to be significantly more important by the MS group as compared to the other two groups ( Table 2 ).

\section{Knowledge}

In the survey about the state of knowledge concerning reproduction and fertility, merely 20 (4.0\%) of the 498 participants achieved a score of at least 11 points and thus demonstrated a good knowledge of the subjects. Most of the participants $(296=59.4 \%)$ with scores of 6 to 10 points had a moderate knowledge while more than a third scored 5 or less points ( $182=36.5 \%$ ), corresponding to a poor knowledge. The MS group $(\mathrm{M}=7.39, \mathrm{~s}=2.01)$ achieved a higher total score than the AS $(\mathrm{M}=6.08, \mathrm{~s}=2.47)$ and $\mathrm{BS}$ groups $(\mathrm{M}=5.61, \mathrm{~s}=2.27) \quad(\mathrm{F}$ $[2]=25.02, p<0.001)$. Also appreciably more members of the MS group achieved a score of at least 11 points (7.8\%) than those of the AS (3.2\%) and BS groups (1.3\%) and significantly less MS belonged to the group with the lowest knowledge (MS $17.0 \%$, AS $41.1 \%$, BS $50.3 \%)$. Women $(M=6.72, s=2.33$ ) were signifi- 


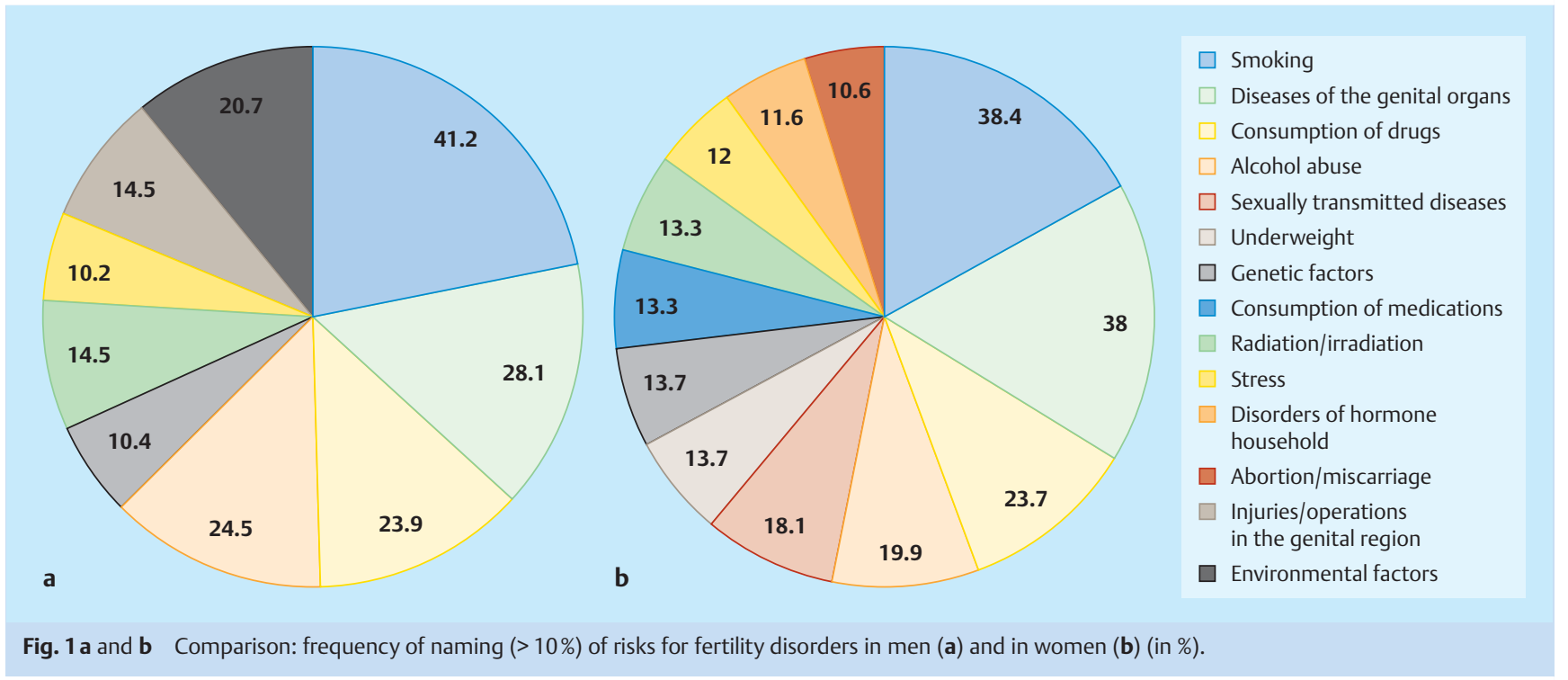

cantly better informed than the men $(\mathrm{M}=5.73, \mathrm{~s}=2.35)(\mathrm{F}$ $[1]=21.11, \mathrm{p}<0.001$ ).

There was a statistically significant negative correlation between the state of knowledge of the participants $\left(r_{s}=-0,105\right)$ and the risk score as well as with an involvement with the topic fertility already in the past $\left(r_{S}=-0,125\right)$. However, the common variance here is very small, as it is also for the (significant) relationship between the state of knowledge and the already achieved highest school leaving certificate $\left(r_{s}=0,127\right)$.

\section{Risk behaviour of the participants}

On average the participants in the survey achieved a risk total score of $M=3.50(s=1.99, \min =0, \max =9)$. Here the differences between the groups were significant: $\mathrm{BS}(\mathrm{M}=4.39, \mathrm{~s}=2.09)$ exhibited more risky behaviour than AS $(\mathrm{M}=3.55, \mathrm{~s}=1.78)$ and $\mathrm{MS}$ $(\mathrm{M}=2.57, \mathrm{~s}=1.79)(\mathrm{F}[2]=35.83, \mathrm{p}<0.001)$. Women $(\mathrm{M}=3.21$, $\mathrm{S}=2.00)$ led significantly less risky lives than their male contemporaries $(\mathrm{M}=3.96, \mathrm{~s}=1.89)(\mathrm{F}[1]=16.64, \mathrm{p}<0.001)$.

There was a particularly large difference in the frequency of nicotine consumption. Only $10.5 \%$ of the MS group admitted to being current smokers. In the AS group 18.0\% were current smokers which was still markedly fewer than in the BS group where more than every second member was a smoker (51.6\%) $(\mathrm{F}[2]=46.87, \mathrm{p}<0.001)$.

\section{Motives for wanting children}

As in the survey by Stöbel-Richter et al. [16] "emotional stabilisation and leading a meaningful life" were the strongest motivations for starting a family. There were no significant differences between the questioned groups between men and women ( $\mathrm{F}$ $[2]=0.36 ; p=0.7$ or, respectively, $F[1]=0.13, p=0.72$ ). "Personal limitations and problems" ( $\mathrm{M}=2.35, \mathrm{~s}=0.68)$ as well as "insufficient material and social support" ( $M=2.23, \mathrm{~s}=0.64)$ were considered by all three groups of participants to be the most important arguments against starting a family. There was a significant difference between the assessment of material impairments that were considered by MS ( $M=2.17, \mathrm{~s}=0.59)$ to be of lesser importance than by AS $(\mathrm{M}=2.21, \mathrm{~s}=0.65)$ and $\mathrm{BS}(\mathrm{M}=2.34, \mathrm{~s}=0.64)(\mathrm{F}$ $[2]=3.59, \mathrm{p}=0.028)$. "Social recognition and creating an identity" by the parents of children is also an important consideration in all three groups ( $\mathrm{M}=1.82, \mathrm{~s}=0.64)$ but of markedly less influence than the emotional aspect. For men $(M=1.97, s=0.71)$ social recognition is significantly more important than it is for their female counterparts $(\mathrm{M}=1.73, \mathrm{~s}=0.58)(\mathrm{F}[1]=16.62, \mathrm{p}<0.001)$.

The selected motive for having children "insufficient material and social support" correlated positively with the risk score, the motive "emotional stabilisation and creating an identity" correlated negatively with the wish for more information on the topic of fertility risks.

\section{Personal characteristics}

On evaluation of the personality scale of the Big Five Inventory, merely two attribute dimensions showed significant differences between the participating groups. These were on the one hand the assessment of "conscientiousness" that MS $(M=3.97$, $S=0.49)$ considered to be more appropriate for themselves than BS $(\mathrm{M}=3.89, \mathrm{~s}=0.60)$ and AS $(\mathrm{M}=3.81, \mathrm{~s}=0.54)(\mathrm{F}[2]=3.45$, $\mathrm{p}=0.032$ ) and, on the other hand, the surveyed MS considered themselves to be significantly stronger in "openness to experience" $(M=3.93, s=0,69)$ than did the AS $(M=3.83, s=0.70)$ and the $B S(M=3.59, s=0.70)(F[2]=9.65, p<0.001]$. With regard to extraversion, tolerability and neuroticism there were no differences.

The correlations between personality factors and the variables state of knowledge, risk score and wish for information were not significant. Only the correlation between neuroticism and the total sum score depressiveness was, as expected, highly positive $\left(r_{\mathrm{s}}=0,434\right)$.

\section{Psychic state}

In the assessment of own depressiveness in the PHQ-D, significant differences were apparent above all between the two student groups. In the sense of the PHQ evaluation, 53.5\% of the participants did not exhibit a depressive disorder, $36.0 \%$ showed a slight depressive disorder and $10.7 \%$ a major depression $(7.5 \%$ of medium severity, $2.6 \%$ of pronounced severity, $0.6 \%$ of the most severe degree, see $\bullet$ Fig. 2).

MS considered themselves in their own estimation to be significantly less depressive $(M=4.06, s=3.50)$ than the AS $(M=5.41$, $\mathrm{S}=3.48, \mathrm{P}[\mathrm{F}]=0,017)$ and almost significantly less depressive 


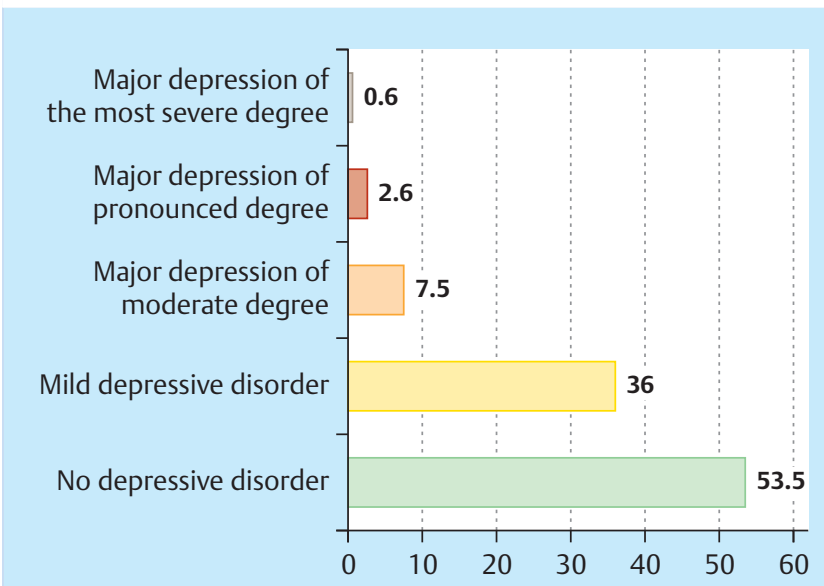

Fig. 2 Distribution of the total scores for depressiveness in the entire tested population (after PHQ-subgroup division, in \%).

than the $B S(M=5.35, s=4.14, P[F]=0.078)$. There was no significant difference between AS and BS.

A significant opposite but lower relationship was found between the extent of depressiveness and a previous confrontation with the topic fertility in the past. On the other hand there was a highly positive correlation between the total score for depressiveness and the risk score $\left(r_{s}=0.458\right)$.

In the light of these results, it was checked by means of a multiple step-wise regression which variables were the most suitable to predict the total risk score. At first as predictors the variables state of knowledge, desire for information, motive for starting a family, personality characteristics and depressiveness were included in the analysis. The final model encompassed significantly positive relationships for depressiveness, (lack of) knowledge and high values on the LKM scale "personal limitations and problems", which reflect that children are rather considered to be a problem ( $\bullet$ Table 4 ). The other mentioned variables did not show any significant influence.

\section{Discussion}

$\nabla$

The present survey provides important indications for a specific health education with the help of which further increases in the number of involuntarily childless couples could be prevented. On account of the low number of participants and the specifically addressed subgroups, the study is not representative, however, in this way a highly homogeneous population sample could be examined. It should be validated by means of a representative survey. A world-wide survey of 17500 persons, mostly also of childbearing age, from 10 countries in Europe, Africa, the Middle East and South America from 2006 [20] also revealed a large deficit in knowledge on fertility and reproduction, but a direct comparison is not possible due to larger variances in the social demographic characteristics.

The results described in the present study on the state of knowledge of the participants confirm this knowledge gap: merely $4 \%$ of the entire tested population showed consolidated knowledge in that they answered at least 11 of 16 posed questions correctly, more than one third of the participants (36.5\%) were not even able to answer more than 5 questions correctly, of the less well educated vocational trainees this held for more than half of them (50.32\%). Knowledge about, for example, the start and duration of a woman's fertile days and the survival time of sperm cells is absolutely essential in order to be able to correctly assess the time point for unprotected sexual intercourse [13]. This could explain why, according to a study by Pook et al., $50 \%$ of the couples did not have sexual intercourse during the optimal time period for conception in spite of the desire to have children [21].

The increasing age of the women was correctly assessed by the participants of the study as a decisive risk factor for fertility, however, upon closer questioning it was found that here also exact knowledge was lacking: the decrease of a woman's fertility by $50 \%$ was stated to occur on average at the age of 40.02 years. This estimation of the participants was wrong by 5 years [22]. These underestimations of the decreases in female fertility with increasing age are in accord with the results of previous studies [5, 14], Bretherick et al. reported on a lack of awareness by female students of the rapid decline of female fertility with increasing age. Also on assessment of other factors, e.g., smoking or underweight, the participants recognised a risk for fertility. However, it is probable that the participants made use of their knowledge about risks for health in general [13]. This is also apparent in the grading risk assessment whereby the three lifestyle factors that definitely have a negative impact on fertility (increasing age of the woman, smoking, overweight [6]) did not occupy the first three places, rather, besides the medical influencing factors such as diseases of the sexual organs and hormone disorders, e.g., the influence of drugs was considered to be far more harmful for fertility than, for example, obesity. All risk factors assessed as being significantly different were rated more strongly by MS than by AS and BS. Marked differences $(p<0.001)$ were seen in the assessment of hormone disorders, radiation/irradiation, chemotherapy, stress, underweight, mental stress, environmental stress, chronic diseases, anxiety disorders and competitive sports which the MS on account of their pre-existing medical knowledge considered to be significantly more harmful for fertility than their not medically trained counterparts.

Even when young men and women are aware of the risks for possible fertility disorders this does not mean that they will avoid them. In the present study the BS estimated smoking to be a strong risk factor for fertility with 4.38 of a maximum 5 points, even so more than $50 \%$ of this test group were smokers. A com-

Table 4 Results of the step-wise linear regression - criterion total risk score.

\begin{tabular}{lccccc} 
Predictor & Beta & $\mathbf{t}$ & Significance & Corrected $\mathbf{R}^{\mathbf{2}}$ & ${\text { Change of } \mathbf{R}^{\mathbf{2}} \mathbf{t}}$ \\
Total sum score depressiveness & 0.441 & 10.58 & $<0.001$ & 0.201 & 0.202 \\
\hline State of knowledge & -0.109 & -2.60 & 0.010 & 0.208 & 0.009 \\
\hline LKM scale: personal limitations and problems & 0.096 & 2.29 & 0.023 & 0.215 & 0.009
\end{tabular}

Depressiveness, state of knowledge and LKM scale significantly predict risk behaviour with a maximum variance in terms of $21.5 \%$. 
parison with the result of MS with those of the other two groups speaks for better clarification: MS are significantly better informed, consider themselves to be conscientious persons (according to results of BFI-K) and behave in a less risky manner than their contemporaries.

Emphasis should be placed on the relationship between depressiveness and risk behaviour that was clearly apparent not only in the correlation but also in the regression analysis. In comprehensive clarification, therefore, psychosocial aspects and their relevance for behavioural changes of the respective person should also be taken into consideration in order to recognise mental diseases in good time and to initiate appropriate therapies if needed. An investigation of more than 2000 pregnant women revealed that an accumulation of negative life-style factors such as smoking, alcohol, consumption of tea/coffee, obesity, and social isolation can reduce the probability of conception within one year, namely from $83.3 \%$ in the absence of such factors to $38.4 \%$ in the presence of four of the mentioned factors [7].

The regression analysis of the Leipzig questionnaire on the desire for children revealed that especially those participants who view children above all in connection with "personal limitations and problems" also practice a more risky life-style. Also in the field of attitudes related to the desire to have children starting points for prevention campaigns may be found.

Almost two-thirds of the participants (62.4\%) wished for more information on the topic fertility and its risk factors, e.g., in the form of posters. Women above all answered the question of a desire for information with yes (69.9\%). The present study thus reveals an existing demand for information among young people, this is not only important for the success of prevention programmes but also provides a foundation for discussions on possible strategies and contents for the prevention of fertility disorders.

\section{Conclusion}

\section{$\nabla$}

When young couples consult a gynaecologist concerning an unfulfilled desire to have children it is as a rule too late for preventative options. Thus it appears to be important in the gynaecological practice to explain during the first contact with the young patients in the sense of a life-style counselling about the adverse effects on fertility, even when the efficacy of such steps has as yet not been validated [12]. An even better strategy would be a primary preventative clarification in schools in the framework of which not only the prevention of pregnancies but also the protection of fertility could be described.

\section{Conflicts of Interest \\ $\nabla$}

None.

\section{References}

1 Statistisches Bundesamt. Mikrozensus 2008 - Neue Daten zur Kinderlosigkeit in Deutschland. Begleitmaterial zur Pressekonferenz am 29. Juli 2009 in Berlin. Juli 2009, Wiesbaden

2 Höhn C Ette A, Ruckdeschel K. Kinderwünsche in Deutschland. Konsequenzen für eine nachhaltige Familienpolitik. Bundesinstitut für Bevölkerungsforschung. Robert Bosch-Stiftung $\mathrm{GmbH}$, Hrsg. Stuttgart: Steinkopf Druck; 2006

3 Sütterlin S, Hoßmann I. Berechnungen. Ungewollt kinderlos. Was kann die moderne Medizin gegen den Kindermangel in Deutschland tun? Berlin-Institut für Bevölkerung und Entwicklung, Hrsg. Köln: Gebrüder Kopp GmbH \& Co. KG; 2007

4 Stöbel-Richter $Y$, Weidner $K$, Förster $P$ et al. Familiengründung in Deutschland. Wie geplant sind Kinderwunsch, Schwangerschaft und Kinderlosigkeit? Gynäkologische Endokrinologie 2008; 6: 177-184

5 Wang YA, Healy D, Black DA et al. Age-specific success rate for women undertaking their first assisted reproduction technology treatment using their own oocytes in Australia, 2002-2005. Hum Reprod 2008; 23: 1633-1638

6 Homan GF, Davies M, Norman R. The impact of lifestyle factors on reproductive performance in the general population and those undergoing infertility treatment: a review. Hum Reprod Update 2007; 13: 209-223

7 Hassan MA, Killick SR. Negative lifestyle is associated with a significant reduction in fecundity. Fertil Steril 2004; 81: 384-392

8 Berger $U$, Wick $K$, Brix $C$ et al. Primary prevention of eating related problems in the real world. J Public Health 2011; 19: 357-365

9 Künzle R, Mueller MD, Hänggi W et al. Semen quality of male smokers and nonsmokers in infertile couples. Fertil Steril 2003; 79: 287-291

10 Baron JA, La Vecchia C, Levi F. The antiestrogenic effect of cigarette smoking in women. Am J Obstet Gynecol 1990; 162: 502-514

11 Anderson $K$, Nisenblat $V$, Norman RJ. Lifestyle factors in people seeking infertility treatment - a review. Aust N Z J Obstet Gynaecol 2010; 50: 8-20

12 Anderson K, Norman RJ, Middleton P. Preconception lifestyle advice for people with subfertility. Cochrane Database Syst Rev 2010; 4: CD008189

13 Bunting L, Boivin J. Knowledge about infertility risk factors, fertility myths and illusory benefits of healthy habits in young people. Hum Reprod 2008; 23: 1858-1864

14 Bretherick KL, Fairbrother N, Avila L et al. Fertility and aging: do reproductive-aged Canadian women know what they need to know? Fertil Steril 2010; 93: 2162-2168

15 Carl C, Bengel J, Strauß B. Gewollte Kinderlosigkeit aus psychologischer Perspektive. Reproduktionsmedizin 2000; 16: 28-36

16 Stöbel-Richter Y, Beutel ME, Finck $C$ et al. The 'wish to have a child', childlessness and infertility in Germany. Hum Reprod 2005; 20 : 2850-2857

17 Rammstedt B, John OP. Kurzversion des Big Five Inventory (BFI-K): Entwicklung und Validierung eines ökonomischen Inventars zur Erfassung der fünf Faktoren der Persönlichkeit. Diagnostica 2005; 51: 195206

18 Gräfe K, Zipfel S, Herzog W et al. Screening psychischer Störungen mit dem „Gesundheitsfragebogen für Patienten (PHQ-D)“ Ergebnisse der deutschen Validierungsstudie. Diagnostica 2004; 50: 171-181

19 Herpertz S, Köllner V. Gesundheitsverhalten und Psychotherapie. Psychotherapie im Dialog 2008; 9: 317-318

20 World Fertility Awareness Month. What you never know about fertility [Brochure]. 2006

21 Pook M, Tuschen-Caffier B, Krause W et al. Psychische Gesundheit und Partnerschaftsqualität idiopathisch infertiler Paare. In: Brähler E, Felder H, Strauß B, Hrsg. Fruchtbarkeitsstörungen. Jahrbuch der Medizinischen Psychologie. Band 17. Göttingen: Hogrefe; 2000: 262-271

22 Dunson DB, Colombo B, Baird DD. Changes with age in the level and duration of fertility in the menstrual cycle. Hum Reprod 2002; 17: 13991403
Deutschsprachige Zusatzinformationen online abrufbar unter:

www.thieme-connect.de/ejournals/toc/gebfra. 